Jurnal Media Pertanian Vol. 1 No. 1 Tahun 2016 Hal. 11 - 17

Media Komunikasi Hasil Penelitian dan Review Literatur Bidang Ilmu Agronomi

ISSN $2503-1279$

\title{
RESPON PERTUMBUHAN BIBIT KELAPA SAWIT (Elaeis guineensis Jacq.) TERHADAP APLIKASI PUPUK N-P-K (12-0,6-6)
}

\author{
Nasamsir \\ Program Studi Agroteknologi, Fakultas Pertanian Universitas Batanghari \\ Jl. Slamet Riyadi-Broni, Jambi. 36122, Telp. +62074160103 \\ email : nasamsirsamsir@yahoo.co.id
}

\begin{abstract}
This research aims to know the oil palm seedling growth response in the main nursery toward $\mathrm{N}-\mathrm{P}-\mathrm{K}(12-0,6-6)$ fertilizer with the trademark Vedagro with different doses. The research was carried out in the Paal Merah Lama village, Southern Jambi sub district, started from 16 September until 16 Desember 2015. The research design used was Completely Randomized Design, with fertilizer dose of Vedagro as a treatment which consists of 6 levels, namely: d0 (control), d1 (5 g polybag $\left.{ }^{-1}\right), d 2\left(10 \mathrm{~g}_{\text {polybag }}{ }^{-1}\right), d 3\left(15 \mathrm{~g} \mathrm{polybag}^{-1}\right), d 4\left(20 \mathrm{~g}_{\text {polybag }}{ }^{-1}\right)$ and $d 5$ (25 $\mathrm{g}$ polybag $\left.{ }^{-1}\right)$, using 4 replicates. The observed variables a plant height, totally plant leaf area, plant dry weight, and shoot-root ratio. The material used is oil palm seedlings aged 3 mounths. Data were analyzed using analysis of varians, then continued by Duncan test (DNMRT) at the 5\% level. The results showed that giving real effect against the Vedagro fertilizer to plant height, totally plant leaf area, plant dry weight, and shoot-root ratio. $20 \mathrm{~g}$ dose of Vedagro fertilizer, showed the best effect on seeds height and dry weight, while the best effect on shoot-root ratio and totally plant leaf area was in $15 \mathrm{~g}$ dose
\end{abstract}

Keywords; the growth of plants, fertilizer application

\begin{abstract}
Abstrak
Penelitian ini bertujuan untuk mengetahui respon pertumbuhan bibit kelapa sawit di pembibitan utama terhadap pemberian pupuk N-P-K (12-0,6-6) (merek dagang Vedagro) dengan dosis yang berbeda. Penelitian dilaksanakan di kelurahan Paal Merah Lama kecamatan Jambi Selatan, mulai 16 September sampai 16 Desember 2015. Rancangan yang digunakan adalah Rancangan Acak Lengkap (RAL), yaitu dosis pupuk Vedagro yang terdiri dari 6 level yaitu, d0 (kontrol), d1 $\left(5 \mathrm{~g} \mathrm{polybag}^{-1}\right), \mathrm{d} 2\left(10 \mathrm{~g}_{\text {polybag }}{ }^{-1}\right), \mathrm{d} 3\left(15 \mathrm{~g} \mathrm{polybag}^{-1}\right), \mathrm{d} 4\left(20 \mathrm{~g} \mathrm{polybag}^{-1}\right)$ dan d5 (25 g polybag $^{-1}$ ), dengan 4 ulangan. Peubah yang diamati adalah tinggi tanaman, luas daun total, berat kering tanaman dan nisbah tajuk akar. Bahan yang digunakan adalah bibit kelapa sawit berumur 3 bulan. Analisis data menggunakan analisis ragam dan dilanjutkan dengan uji Duncan (DNMRT) pada taraf $\alpha 5 \%$. Hasil penelitian menunjukkan bahwa pemberian pupuk Vedagro berpengaruh nyata terhadap tinggi bibit, luas daun total, berat kering tanaman dan nisbah tajuk akar. Pemberian pupuk Vedagro dengan dosis $20 \mathrm{~g}_{\text {polybag }}{ }^{-1}$ memperlihatkan pengaruh terbaik terhadap tinggi bibit dan berat kering bibit, sedangkan dosis $15 \mathrm{~g}$ polybag $^{-1}$ menghasilkan pengaruh terbaik pada nisbah tajuk akar dan luas daun total.
\end{abstract}

Kata kunci ; pertumbuhan tanaman, aplikasi pupuk

\section{PENDAHULUAN}

Kelapa sawit merupakan salah satu komoditi sub sektor perkebunan yang memberikan andil besar dalam pemasukan devisa negara di luar sektor minyak dan gas bumi. Komoditas ini juga menyerap tenaga kerja yang cukup besar dan mampu memberikan kemakmuran bagi masyarakat yang mengusahakannya (Risza, 1994).

Tanaman kelapa sawit termasuk tanaman multiguna. Tanaman tersebut mulai banyak menggantikan posisi penanaman komoditas perkebunan lain, yaitu tanaman 
Jurnal Media Pertanian Vol. 1 No. 1 Tahun 2016 Hal. 11 - 17

Media Komunikasi Hasil Penelitian dan Review Literatur Bidang Ilmu Agronomi

ISSN $2503-1279$

karet. Tanaman kelapa sawit kini tersebar di berbagai daerah. Secara umum dapat diindikasikan bahwa pengembangan perkebunan kelapa sawit masih mempunyai prospek harga, ekspor, dan pengembangan produk (Suwarto dan Octavianty, 2010).

Berdasarkan data Direktur Jenderal Perkebunan Kementerian Pertanian pada tahun 2014 luas areal perkebunan kelapa sawit di Provinsi Jambi 688.810 dengan produksi 1.857.260. tanaman kelapa sawit saat ini tersebar di hampir seluruh provinsi di Indonesia. Provinsi Riau dengan luas areal 2,30 juta Ha merupakan provinsi yang mempunyai perkebunan kelapa sawit terluas disusul berturut-turut Provinsi Sumatera Utara seluas 1,39 juta Ha, Provinsi Kalimantan Tengah seluas 1,16 juta Ha dan Sumatera Selatan dengan luas 1,11 juta $\mathrm{Ha}$ serta provinsi-provinsi lainnya (Dirjen perkebunan, 2014).

Salah satu aspek yang perlu mendapat perhatian didalam menunjang program pengembangan pertanaman Kelapa sawit adalah penyediaan bibit yang sehat, potensinya unggul dan tepat pada waktunya (Sujarwo, 2008). Untuk mendapat bibit yang baik perlu diciptakan kondisi yang mendukung pertumbuhannya di pembibitan, seperti ketersediaan unsur hara, baik makro, maupun mikro (Sudarianto dan Wibawa, 1994).

Ketersediaan unsur hara di dalam tanah harus cukup dan seimbang, oleh karena itu diperlukan penambahan unsur hara dengan jalan pemberian pupuk. Agar pertumbuhan bibit kelapa sawit normal dibutuhkan unsur hara $\mathrm{N}, \mathrm{P}, \mathrm{K}$ dan $\mathrm{Mg}$ yang cukup dan seimbang. Saat ini pupuk yang banyak digunakan oleh masyarakat adalah pupuk tunggal seperti, Urea, ZA, dan KCL. Penggunaan pupuk tunggal ini kurang efisien karena pupuk tunggal sangat mudah menguap dan tercuci oleh air sehingga tidak seluruhnya dapat diserap dengan optimal oleh tanaman.

Salah satu upaya yang efektif untuk meningkatkan serapan pupuk oleh tanaman adalah dengan menggunakan pupuk yang dapat tersedia secara bertahap sesuai dengan kebutuhan tanaman. Pupuk seperti ini diperoleh dengan cara perbaikan sifat pupuk melalui teknik manipulasi proses pembuatannya (Goenadi, 1990 dalam Goenadi 1992). Menurut Goenadi (1992), dari manipulasi proses pembuatan pupuk diperoleh pupuk dengan bentuk, ukuran, kadar hara dan bahan pembawa tertentu dalam kombinasi yang optimal sehingga menghasilkan efektifitas yang lebih tinggi (efektifitas kelarutan yang tinggi, konsistensi kelarutan unsur hara yang sesuai dengan kebutuhan tanaman dan tingkat kehilangan unsur hara pupuk di dalam media rendah).

Pupuk Vedagro mengandung unsur hara makro seperti $\mathrm{N}: 11-12 \%, \mathrm{~K}_{2} \mathrm{O}: 4,5-6 \%$, $\mathrm{P}_{2} \mathrm{O}_{5}: 0,4-0,6 \%, \mathrm{Ca}: 1,1 \%, \mathrm{Mg}: 1,9-2,2 \%$. Sedangkan unsur hara mikro terdiri dari Fe, $\mathrm{Mn}, \mathrm{Cu}, \mathrm{Zn}, \mathrm{B}, \mathrm{Co}$, Mo dan $\mathrm{Pb}$. Selain kandungan unsur hara makro dan mikro di atas, pupuk ini juga mengandung asam amino yang bermanfaat seperti Aspartic acid, Thrconine, Serine, Glutamic acid, Glycinie, Alanine, Valine, Isolccine, Leucine, Tyrosine, Phenylalanine, Lysine dan Arginine (Anonim, 2010).

Disebutkan juga, pupuk ini memiliki beberapa kelebihan antara lain : (1) bersifat slow release (terurai secara perlahan sehingga penyerapan unsur hara lebih efisien), (2) mengembalikan atau menjaga keseimbangan ekosistem, meningkatkan kondisi kehidupan mikroorganisme tanah, (3) meningkatkan kondisi fisik atau struktur tanah, melancarkan sirkulasi air dan udara dalam tanah, (4) tidak berbahaya bagi tanaman apabila terjadi kelebihan pemupukan, serta aman dan ramah lingkungan (Anonim, 2010). 
Jurnal Media Pertanian Vol. 1 No. 1 Tahun 2016 Hal. 11 - 17

Media Komunikasi Hasil Penelitian dan Review Literatur Bidang Ilmu Agronomi

ISSN $2503-1279$

\section{METODE PENELITIAN}

Penelitian ini dilaksanakan di kelurahan Paal Merah Lama kecamatan Jambi Selatan. Ketinggian tempat $\pm 35 \mathrm{~m}$ di atas pemukaan laut, dengan curah hujan rata-rata $1500 \mathrm{~mm}$ per tahun, datar dan dekat dengan sumber air. Pengukuran berat kering tanaman dilakukan di Laboratorium Dasar Fakultas Pertanian Universitas Batanghari Jambi. Penelitian dilaksanakan selama 3 bulan mulai 16 September sampai 16 Desember 2015.

Bahan yang digunakan dalam penelitian ini adalah bibit kelapa sawit Tenera berumur 3 bulan yang berasal dari Marihat Medan, air, tanah lapisan atas, pasir, pupuk Vedagro dan polybag warna hitam ukuran $35 \mathrm{~cm}$ X $40 \mathrm{~cm}$. Sedangkan alat-alat yang digunakan adalah cangkul, parang, ayakan, handspayer, ember plastik, meteran, penggaris, timbangan analitik, oven, desikator, amplop besar, dan alat-alat tulis.

Penelitian ini dirancang menggunakan Rancangan Acak Lengkap (RAL) dengan satu faktor perlakuan, yaitu 6 level dosis pupuk Vedagro ; $\mathrm{d}_{0}=0 \mathrm{~g}$ (kontrol), $\mathrm{d}_{1}=5 \mathrm{~g}$ polibag $^{-1}, \mathrm{~d}_{2}=10 \mathrm{~g}$ polibag $^{-1}, \mathrm{~d}_{3}=15 \mathrm{~g}$ polibag $^{-1}, \mathrm{~d}_{4}=20 \mathrm{~g}$ polibag $^{-1}$, dan $\mathrm{d}_{5}=25 \mathrm{~g}$ polibag $^{-}$

${ }^{1}$ Setiap perlakuan diulang $4 \mathrm{kali}$, sehingga satuan percobaan berjumlah 24. Setiap satuan percobaan terdiri dari 3 tanaman, 2 tanaman ditentukan secara acak sebagai sampel. Peubah yang diamati adalah tinggi bibit $(\mathrm{cm})$, luas daun total $\left(\mathrm{cm}^{2}\right)$, bobot kering tanaman $(\mathrm{g})$, dan nisbah tajuk akar

Untuk melihat dinamika pertumbuhan, hasil pengukuran 15 hari sekali sampai bibit berumur 90 HST (12 MST) ditampilkan dalam bentuk grafik. Untuk melihat pengaruh masing-masing perlakuan terhadap peubah yang diamati, hasil pengamatan akhir dianalisis secara statistik dengan uji varian dan dilanjutkan dengan Uji Jarak Berganda Duncan (DNMRT) $\alpha=5 \%$.

\section{HASIL dan PEMBAHASAN}

Berdasarkan hasil analisis statistik didapatkan bahwa pemberian pupuk Vedagro berpengaruh nyata terhadap tinggi, luas daun total, berat kering tanaman, dan nisbah tajuk akar bibit Kelapa sawit pada umur 12 MST yang disajikan pada tabel berikut.

Tabel 1. Rata-rata tinggi, luas daun total, berat kering tanaman, dan nisbah tajuk akar bibit Kelapa sawit pada berbagai dosis pupuk Vedagro pada umur 12 MST

\begin{tabular}{|c|c|c|c|c|}
\hline Dosis Vedagro (gr) & Tinggi Bibit & $\begin{array}{l}\text { Luas Daun } \\
\text { Total (cm2) }\end{array}$ & $\begin{array}{c}\text { Bobot Kering } \\
\text { (gr) }\end{array}$ & $\begin{array}{c}\text { Nisbah Tajuk } \\
\text { Akar }\end{array}$ \\
\hline $\mathrm{d} 4(20 \mathrm{~g})$ & $33.55 \mathrm{a}$ & $115.01 \mathrm{a}$ & $0.46 \mathrm{a}$ & $0.72 \quad \mathrm{a}$ \\
\hline $\mathrm{d} 3(15 \mathrm{~g})$ & $32.14 \mathrm{a}$ & $98.07 \mathrm{~b}$ & $0.26 \mathrm{~b}$ & 0.60 \\
\hline $\mathrm{d} 2(10 \mathrm{~g})$ & $29.34 \mathrm{~b}$ & $95.63 \mathrm{~b}$ & $0.24 \mathrm{bc}$ & 0.59 \\
\hline $\mathrm{d} 1(5 \mathrm{~g})$ & $28.38 \mathrm{~b}$ & $78.72 \mathrm{c}$ & $0.20 \mathrm{bc}$ & 0.58 \\
\hline $\mathrm{d} 5(25 \mathrm{~g})$ & $26.43 \mathrm{c}$ & $78.16 \mathrm{c}$ & $0,19 \mathrm{bc}$ & 0,57 \\
\hline d0 (kontrol) & $24.87 \mathrm{~d}$ & $39.07 \mathrm{~d}$ & $0,14 \quad \mathrm{c}$ & 0,46 \\
\hline
\end{tabular}

Keterangan : angka-angka yang diikuti oleh huruf yang sama tidak berbeda nyata pada taraf $\alpha 5$ $\%$ uji Duncan.

Pada dasarnya pertumbuhan dan perkembangan tanaman adalah hasil aktivitas metabolisme sel-sel nya. Hasil metabolisme tidak hanya menyediakan bahan baku pertumbuhan dan perkembangan tetapi juga menyediakan energi untuk semua proses yang terjadi dalam tubuh tanaman. Pertumbuhan tanaman ditunjukkan oleh adanya pertambahan ukuran dan berat kering tanaman. Pertambahan ini mencerminkan bertambahnya protoplasma yang mungkin terjadi baik karena ukuran maupun jumlah sel nya bertambah (Harjadi,1991). Selain dicerminkan oleh berat kering, pertumbuhan 
Jurnal Media Pertanian Vol. 1 No. 1 Tahun 2016 Hal. 11 - 17

Media Komunikasi Hasil Penelitian dan Review Literatur Bidang Ilmu Agronomi

ISSN $2503-1279$

tanaman juga ditunjukkan oleh adanya peningkatan tinggi tanaman, diameter batang dan juga luas daun tanaman (Sitompul, 1995).

Pupuk Vedagro mengandung unsur nitrogen yang merupakan unsur hara utama bagi pertumbuhan tanaman karena menjadi penyusun dari banyak senyawa bagi tumbuhan seperti protein dan enzim (Anonim, 2010). Pertumbuhan akan lebih cepat apabila protein yang dibentuk semakin banyak, karena senyawa tersebut sangat diperlukan untuk pembentukan sel-sel baru. Nitrogen dalam pupuk yang diserap tanaman segera akan merangsang pertumbuhan secara keseluruhan khususnya tinggi tanaman, batang dan daun.

Selanjutnya kandungan fospor berpengaruh terhadap pertumbuhan dan perkembangan tanaman. Hal ini disebabkan fospor berperan dalam merangsang pertumbuhan dan perakaran tanaman (Nyakpa et.al, 1998). Selanjutnya Winarso, 2005 menyatakan bahwa unsur fospor merupakan bagian dari inti sel yang sangat penting dalam pembelahan sel dan perkembangan jaringan meristem.

Rauf, Syamsuddin, dan Sihombing. (2000) menyatakan fungsi kalium selain berperan dalam proses fotosintesis juga berperan dalam masuknya $\mathrm{CO}_{2}$ ke dalam daun tanaman melalui stomata. Kandungan kalium yang cukup dalam tanaman akan memberikan peluang lebih besar untuk penggantian $\mathrm{CO}_{2}$ dan $\mathrm{O}_{2}$ dari jaringan tanaman. Selain itu kalium mempercepat aliran air dan produk fotosintesis dalam tanaman, dengan demikian mempercepat penyimpanan fotosintat dalam tanaman.

Dari hasil analisis data tinggi bibit sawit, pemberian pupuk Vedagro dengan dosis $20 \mathrm{~g} \mathrm{polybag}^{-1}(\mathrm{~d} 4)$ memberikan pengaruh tertinggi terhadap tinggi bibit kelapa sawit, berbeda nyata bila dibandingkan dengan rata-rata tinggi bibit kelapa sawit pada perlakuan dosis lainnya. Hal ini memperlihatkan bahwa pupuk Vedagro dengan dosis $20 \mathrm{~g}$ telah mampu untuk meningkatkan pertumbuhan bibit kelapa sawit lebih cepat bila dibandingkan dengan perlakuan lainnya. Hasil ini disebabkan karena nitrogen yang terkandung dalam pupuk Vedagro dapat memacu pertumbuhan vegetatif tanaman. Menurut Nyakpa, et.al, (1988) nitrogen dalam tanaman direduksi menjadi nitrit lalu direduksi menjadi amonia (nitrat), reaksi ini terjadi di dalam kloroplas. Ion amonia diasimilasi menjadi asam glutamat yang berfungsi sebagai bahan dasar dalam biosintesis asam amino dan asam nukleat. Asam amino merupakan pembentuk protein yang merupakan pembentuk protoplasma. Dengan cukupnya jumlah nitrogen pembentukan protoplasma akan meningkat, berarti pembentukan organ vegetatif tanaman akan meningkat pula.

Rendahnya tinggi bibit kelapa sawit pada perlakuan kontrol (d0), diduga akibat tidak adanya penambahan nitrogen di dalam tanah. Nitrogen yang ada dalam tanah akan diserap terus oleh tanaman, maka nitrogen di sekitar tanaman akan habis sehingga pertumbuhan tanaman akan terhambat.

Luas daun total bibit secara statistik berbeda nyata. Meningkatnya luas daun total bibit kelapa sawit diduga karena pengaruh nitrogen yang terkandung dalam pupuk Vedagro. Menurut Gardner, Pearce, dan Mitchell (1991) bahwa pemupukan nitrogen mempunyai pengaruh yang nyata terhadap perluasan daun. Menurut Winarso (2005), bila nitrogen yang tersedia lebih banyak maka dapat dihasilkan protein lebih banyak dan daun dapat tumbuh lebih lebar, akibatnya fotosintat yang dihasilkan lebih banyak pula. Daun yang lebih luas pada perlakuan $\mathrm{d} 3$ bila dibandingkan dengan perlakuan lain memperlihatkan bahwa unsur hara yang terkandung di dalam pupuk Vedagro sudah mampu memberikan hasil yang baik untuk parameter luas daun total. 
Jurnal Media Pertanian Vol. 1 No. 1 Tahun 2016 Hal. 11 - 17

Media Komunikasi Hasil Penelitian dan Review Literatur Bidang Ilmu Agronomi ISSN $2503-1279$

Bobot kering tanaman merupakan total penjumlahan dari bobot kering akar, batang dan daun. Meningkatnya bobot kering tanaman berkaitan erat dengan semakin baiknya pertumbuhan tanaman baik tinggi tanaman maupun luas daun tanaman. Peningkatan bobot kering tanaman pada pemberian pupuk Vedagro dengan dosis $20 \mathrm{~g}$ diduga akibat adanya peningkatan proses fotosintesis pada tanaman dan penambahan unsur hara menghasilkan senyawa-senyawa organik kompleks yang merupakan bagian penting dalam proses pembelahan dan pembesaran sel. Sesuai dengan pendapat Harjadi (1991) bahwa bobot kering tanaman mencerminkan bertambahnya protoplasma yang terjadi karena ukuran sel maupun jumlah sel yang bertambah.

Meningkatnya proses fotosintesis akan meningkatkan jumlah fotosintat. Fotosintat ini sebagian akan ditranslokasikan ke bagian tanaman yang sedang aktif dalam pembelahan dan pertumbuhan sel-sel baru seperti bagian tajuk dan akar. Fotosintat akan terakumulasi dalam bentuk biomassa baik di bagian tajuk maupun akar. Nisbah tajuk akar merupakan nisbah dari bobot kering tajuk dengan bobot kering akar. Semakin berat bobot kering tajuk maka semakin besar nilai nisbah tajuk akarnya dan sebaliknya bila bobot kering akar semakin besar maka nilai nisbah tajuk akar akan semakin kecil.Menurut Sitompul (1995) nisbah tajuk akar sangat ditentukan oleh faktor genetik dan lingkungan.

Perkembangan tinggi bibit kelapa sawit sampai akhir penelitian disajikan pada gambar berikut.

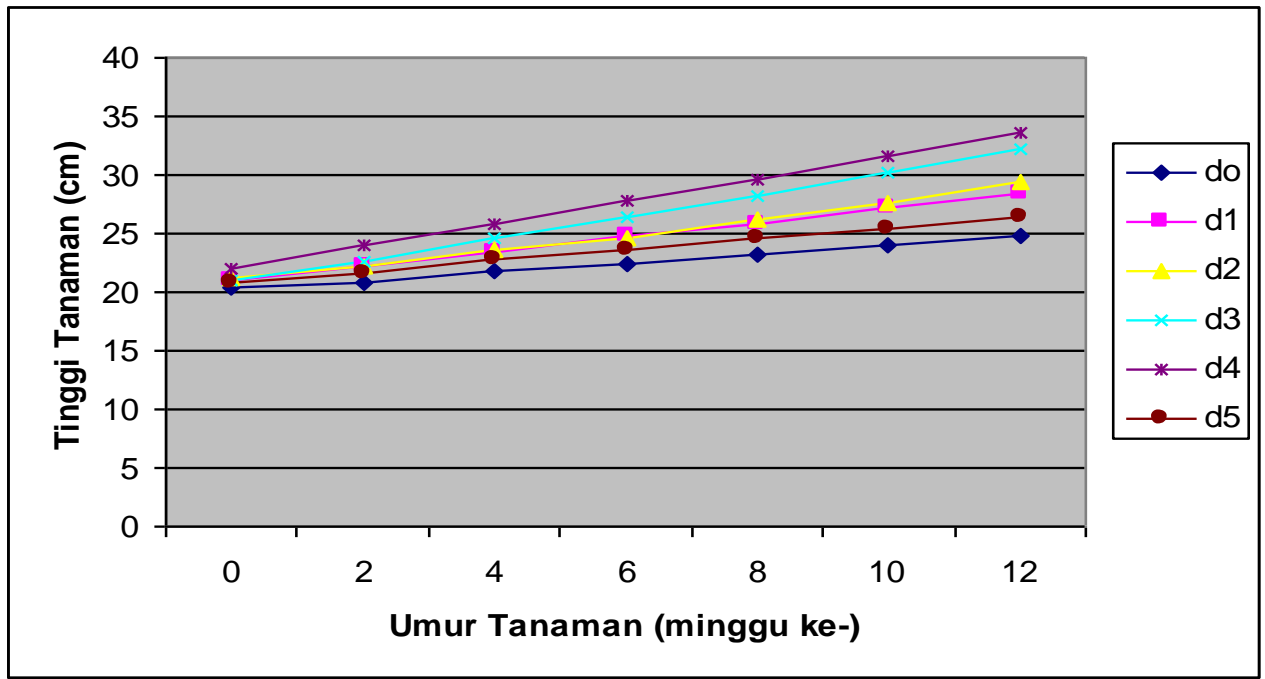

Gambar 1. Perkembangan tinggi bibit Kelapa sawit setelah pemberian berbagai dosis pupuk Vedagro pada umur 2-12 MST.

Dari gambar di atas dapat dilihat, bahwa pertumbuhan tinggi bibit kelapa sawit menunjukkan adanya peningkatan sampai pengamatan pada minggu terakhir, d4 memperlihatkan pertumbuhan yang lebih baik dibandingkan perlakuan lainnya.

\section{KESIMPULAN}

Berdasarkan hasil penelitian dapat diambil kesimpulan bahwa pemberian pupuk Vedagro dengan dosis $5 \mathrm{~g}, 10 \mathrm{~g}, 15 \mathrm{~g}, 20 \mathrm{~g}_{\text {dan }} 25 \mathrm{~g}_{\text {polibag }}{ }^{-1}$ berpengaruh nyata terhadap tinggi, luas daun total, berat kering dan nisbah tajuk akar bibit kelapa sawit serta pemberian pupuk Vedagro dengan dosis $20 \mathrm{~g} \mathrm{polybag}^{-1}$ memperlihatkan pengaruh terbaik pada tinggi bibit dan berat kering bibit, sedangkan pengaruh terbaik pada nisbah tajuk akar dan luas daun total didapatkan pada dosis 15 g.polibag ${ }^{-1}$ 
Jurnal Media Pertanian Vol. 1 No. 1 Tahun 2016 Hal. 11 - 17

Media Komunikasi Hasil Penelitian dan Review Literatur Bidang Ilmu Agronomi

ISSN $2503-1279$

\section{DAFTAR PUSTAKA}

Agustina, L. 1990. Dasar Nutrisi Tanaman. Rineka Cipta, Jakarta.

Anonim, 1981, Vademicum Kelapa Sawit Perkebunan X. Tanjung Karang. , 2006, Laporan Tahunan Dinas Perkabunan Daerah Perkebunan Daerah Tk. 1 Jambi. Pemda Tk. 1 Jambi.

2 2006, Peranan Masing-masing Unsur pupuk bagi Tanaman Kelapa Sawit, brosur pupuk SUPER TE. 2010, Brosur Pupuk VEDAGRO

Bintoro, M.H.1991. Pedoman Budidaya Tanaman Kelapa Sawit. Fakultas Pertanian. IPB. Bogor.

Dwidjoseputro, 1985. Pengantar Fisiologi Tumbuhan. PT. Gramedia, Jakarta.

Gardner, F. P, R. B. Pearce dan R. L. Mitchell. 1991. Fisiologi Tanaman Budidaya. Terjemahan $\mathrm{H}$. Susilo. Universitas Indonesia, Jakarta.

Goenadi, D.H. 1991. Pupuk Lambat Tersedia Manfaatnya Dalam Menjamin Keberhasilan Usaha Tanaman Perkebunan. Pusat Penelitian Perkebunan. Bogor.

Goenadi, D.H. 1992. Keefektifan Pupuk Lambat Tersedia Fertimel Untuk Bibit Tanaman Perkebunan. Menara Perkebunan Bogor. Vol. 60 (4).

Harjadi, S.S. 1991. Pengantar Agronomi. PT. Gramedia, Jakarta.

Ismunadji. 1989. Kalium dan Tanaman Perkebunan dalam Endapan Bahan Kalium di Indonesia (II): 103-19

Lingga, P, 1999. Petunjuk Penggunaan Pupuk. Penebar Swadaya, Jakarta.

Lingga, P. dan Marsono. 2001. Petunjuk Penggunaan Pupuk. Penebar Swadaya. Jakarta.

Lubis. A.U. 1992. Kelapa Sawit di Indonesia. Pusat Penelitian Perkebunan Marihat Pematang Siantar. Medan.

Nyakpa, M.Y, A.M. Lubis, M.A. Pulung, A.G. Munawar, G.B. Hong, Nurhayati hakim. 1998. Kesuburan Tanah. Penerbit Unila.

Risza,S. 1994. Kelapa Sawit. Upaya Peningkatan Produktivitas. Penerbit Kanisius. Yogyakarta.

Salikin, K.A. 2003. Sistem Pertanian Berkelanjutan.Penerbit Kanisius. Yogyakarta. dalam Triyono, A., Purwanto, Budiyono, 2013. Efisiensi Penggunaan Pupuk-N Untuk Pengurangan Kehilangan Nitrat Pada Lahan Pertanian. (Jurusan Teknik Kimia, Fakultas Teknik, Universitas Diponegoro, Semarang).

Sarief, E.S. 1989. Kesuburan dan Pemupukan Tanah Pertanian. Pustaka Buana, Jakarta. Setyamidjaja, 1999 Budidaya Kelapa Sawit. Penerbit Kasinus. Yogyakarta.

Setyawibawa, I. Dan Y.E. Widyastuti. 1996. Kelapa Sawit. Usaha Budidaya, Pemanfaatan Hasil dan Aspek Pemasaran, Penebar Swadaya. Jakarata.

Siagian, B., Kusmini, S. Silitonga,A. Barus dan J. Ginting. 1994. Pengaruh Pupuk Nurseryace dan Zat Pengatur Tumbuh Atonik Terhadap Pertumbuhan Bibit Kelapa Sawit (Elaeis guineensis jacq) di Pembibitan Awal. Universitas Sumatera Utara. Medan.

Sitompul, P, 1995. Pengaruh Beberapa Pupuk Daun Cair Terhadap Pertumbuhan Bibit Okulasi Karet Di Polybag. Skripsi Fakultas Pertanian UNJA, Jambi.

Sudarianto dan A. Wibawa, 1994. Pemberian Pupuk Super Cair Suplemen pada Kopi dan Kakao. Warta Pusat Penelitian Kopi dan Kakao. Jawa Barat. 
Jurnal Media Pertanian Vol. 1 No. 1 Tahun 2016 Hal. 11 - 17

Media Komunikasi Hasil Penelitian dan Review Literatur Bidang Ilmu Agronomi ISSN $2503-1279$

Suhendra, D. 1995. Budidaya dan Pengolahan Kelapa Sawit (Elaeis guineensis Jacq) di Kebun Dolok Ilir, PTP III (Persero) Sumatera Utara. Fakultas Pertanian IPB Bogor.

Sujarwo, A. 2008. Pengaruh Dosis NPK dan Jenis Pupuk Daun Pada Kualitas Pertumbuhan Sirih Merah (Piper crocatum Ruiz and Pav.). Universitas Lampung. Bandar Lampung.

Tjitrosoepomo, G. 1993. Taksonomi Tumbuhan. Gadjah Mada University Press Yogyakarta.

Winarso, S. 2005. Kesuburan Tanah Dasar Kesehatan dan Kualitas Tanah. Gava Media. Yogyakarta. 